\title{
Identifikasi Permasalahan dalam Pengembangan Jalan Tol di Provinsi Jawa Timur
}

\author{
Problem Identification of Toll Road Development in East Java \\ Province
}

\author{
Surya Hadi Kusuma ${ }^{1, a)}$, Belinda Ulfa Aulia ${ }^{1, b)}$ \& Nida Farikha ${ }^{1, c)}$ \\ ${ }^{1)}$ Departemen Perencanaan Wilayah dan Kota, ITS, Surabaya. \\ Koresponden : ${ }^{a}$ surya.uya39@gmail.com, ${ }^{b}$ b3ltown@gmail.com \& ${ }^{c)}$ nidafarikha@gmail.com
}

\begin{abstract}
ABSTRAK
Pengembangan infrastruktur jalan tol menjadi salah satu pemicu pesatnya pertumbuhan dan sebagai pengikat antar wilayah pada Kabupaten/Kota di Provinsi Jawa Timur. Saat ini, berdasarkan buku Rencana Tata Ruang Wilayah (RTRW) Provinsi Jawa Timur Tahun 2011-2031 diketahui terdapat 14 (empat belas) rencana pengembangan jalan tol di Provinsi Jawa Timur dengan total progres adalah sebesar kurang lebih $81 \%$ (delapan puluh satu persen) untuk pembebasan lahan dan kurang lebih $49 \%$ (empat puluh sembilan persen) untuk proses konstruksi. Adapun penelitian ini dilakukan guna mengidentifikasi faktor apa saja yang menjadi penyebab permasalahan dalam pengembangan jalan tol tersebut. Metode yang digunakan adalah melalui analisa deskriptif kualitatif dengan metode indepth interview serta menggunakan analisa pohon masalah (root cause analysis). Secara garis besar, berdasarkan hasil akhir penelitian ini diketahui bahwa permasalahan utama dalam realisasi pembangunan jalan tol di Provinsi Jawa Timur adalah adanya kendala dalam pembebasan lahan baik itu tanah wakaf maupun tanah kas desa, serta adanya perbedaan tahun perencanaan dengan dokumen sektoral level Nasional.
\end{abstract}

Kata Kunci : manajemen aset infrastruktur, jalan tol, faktor permasalahan

\section{PENDAHULUAN}

Perkembangan pembangunan Provinsi Jawa Timur yang terdiri dari 38 Kabupaten/Kota sangatlah pesat. Pesatnya perkembangan pembangunan tersebut tidak jarang memberikan dampak pada menurunnya kualitas lingkungan, dan menyebabkan terjadinya restrukturisasi fungsi kota inti sehingga pemekaran spasial perkotaan yang mengakibatkan terjadinya pergeseran pola penggunaan lahan. Perkembangan spasial memperlihatkan semakin menipisnya polarisasi arah pemusatan kegiatan, perkembangan infrastruktur, dan pemanfaatan ruang secara umum. Hal tersebut terjadi seiring dengan terealisasinya pembangunan infrastruktur yang seperti jalan tol.

Pengertian infrastruktur menurut American Public Works Association (Stone, 1974 dalam Kodoatie,R.J., 2005) adalah fasilitas-fasilitas fisik yang dikembangkan atau dibutuhkan oleh agen-agen publik untuk fungsi-fungsi pemerintahan dalam penyediaan air, tenaga listrik, pembuangan limbah, transportasi dan pelayanan-pelayanan similar untuk memfasilitasi tujuan-tujuan sosial dan ekonomi. Pengadaan infrastruktur membutuhkan banyak dana dan secara teknis, infrastruktur bukanlah objek yang sederhana. Namun, pendanaan selalu terbatas. Infrastruktur sengaja dibangun untuk memenuhi fungsi tertentu yang benar-benar diperlukan. Oleh karena itu, infrastruktur harus dikelola dengan baik agar infrastruktur dapat selalu berfungsi, ekonomis, efektif, efisien dan berkelanjutan (Suprayitno \& Soemitro 2018). 
Seperti yang diketahui, Provinsi Jawa Timur telah memiliki acuan dalam pemanfaatan dan pengembangan wilayahnya yang tertuang dalam Peraturan Daerah Provinsi Jawa Timur Nomor 5 Tahun 2012 tentang Rencana Tata Ruang Wilayah (RTRW) Provinsi Tahun 2011 2031, yang mengacu dan berpedoman pada Undang-Undang Nomor 26 Tahun 2007 tentang Penataan Ruang. RTRW Provinsi diharapkan dapat secara aplikatif berperan sebagai guide pelaksanaan pembangunan, yang mampu meningkatkan produktivitas semua elemen pembangunan wilayah, sekaligus mencegah atau mengurangi tekanan lingkungan oleh berbagai upaya pemenuhan kebutuhan perikehidupan masyarakat. Dalam hal ini rencana tata ruang harus dapat menjembatani dan menjadi payung yang memadukan langkah pembangunan di seluruh Jawa Timur yang terus berkembang. Namun fakta di lapang menunjukkan masih banyak pelaksanaan pembangunan belum sinergis dengan tata ruang dan penempatan lokasinya belum seutuhnya searah dengan aturan yang ditetapkan.

Kegiatan ini dimaksudkan untuk menginventarisir permasalahan dalam pengembangan infrastruktur khususnya jalan tol, serta menstrukturkan akar permasalahannya. Dengan diketahuinya struktur permasalahan pengembangan infrastruktur jalan tol di Provinsi Jawa Timur, diharapkan perumusan strategi penanganan dapat dilakukan dengan lebih efektif dan efisien.

\section{METODA PENELITIAN}

Penilitian ini menggunakan pendekatan induktif dimana penelitian ini menekankan pada pengamatan lalu menarik kesimpulan dari pengamatan tersebut. Metode ini sering disebut sebagai sebuah pendekatan pengambilan kesimpulan dari khusus menjadi umum (Suryabrata, 1993) Pengumpulan data dilakukan adalah dengan survei sekunder dan wawancara secara terstruktur. Adapun teknik analisis data yang digunakan adalah analisis deskriptif kualitatif serta analisis pohon masalah.

\section{Metode Pengambilan Data}

Pengumpulan data dilakukan melalui survei sekunder serta melalui wawancara secara terstruktur selama kurang lebih 2 bulan (September-Oktober 2017). Responden dalam penelitian ini adalah pemangku kepentingan terkait dengan pembangunan infrastruktur jalan tol di Provinsi Jawa Timur. Keluraan yang didapatkan dari proses survei dan wawancara adalah ketercapaian perogram serta masalah yang dihadapi dalam pengembangan jalan tol di Provinsi Jawa Timur.

\section{Metode Analisis Data}

Penelitian ini menggunakan analisis deskriptif kualitatif melalui indepth interview untuk mengetahui bagaimana ketercapaian program pembangunan jalan tol di Provinsi Jawa Timur (Basuki, 2006). Kegiatan ini dimulai dengan melihat ketercapaian program pembangunan jalan tol di Provinsi Jawa Timur melalui kroscek dengan studi literatur dan berbagai dokumen lain serta indepth interview dengan beberapa instansi terkait yaitu Dinas Pekerjaan Umum Bina Marga dan Pematusan Provinsi Jawa Timur serta Dinas Perhubungan Provinsi Jawa Timur. Hal-hal yang ditanyakan dalam indepth interview ini adalah sejauh mana ketercapaian pembangunan jalan tol baik tahap pembangunan maupun pembebasan lahan yang berada pada ruas-ruas berikut:
1) Mantingan -Ngawi
2) Ngawi - Kertosono
3) Kertosono- Mojokerto
4) Mojokerto- Surabaya
5) Gempol - Pandaan
6) Pandaan - Malang

7) Gempol - Pasuruan

8) Pasuruan - Probolinggo

9) Probolinggo - Banyuwangi

10) Gresik - Tuban

11) Tuban - Demak 
12) Surabaya - Suramadu - Tanjung Bulupandan
13) Waru (Aloha) - Wonokromo Tanjung Perak

14) Bandara Juanda - Tanjung Perak

Kemudian analisis pohon masalah digunakan untuk mengetahui permasalahan yang terjadi dalam realisasi program tersebut secara terstruktur melalui hubungan sebab akibat (Scarvada et al, 2004). Teknik analisis ini dipilih karena dengan menggunakan teknik ini maka kita dapat mengetahui apa penyebab utama pemasalahan pembangunan jalan tol di Provinsi Jawa Timur. Sehingga pemerintah dapat memfokuskan pada penyebab strategis dan nantinya akan dapat mengatasi permasalahan lain yang berkaitan. Sehingga diharapkan dengan metode analisis ini maka upaya identifikasi akan lebih mendalam dan tepat sasaran.

Data yang digunakan untuk analisis pohon masalah ini adalah data dari hasil sasaran pertama berupa list ketercapaian program pembangunan jalan tol yang didapatkan dari hasil indepth interview.

\section{ANALISIS PENELITIAN}

Program percepatan penyelesaian pengembangan jalan tol berdasarkan Rencana Tata Ruang Wilayah (RTRW) Provinsi Jawa Timur direncanakan pada 14 (empat belas) ruas jalan tol yang meliputi: Tol Mantingan-Ngawi, Tol Ngawi-Kertosono- Tol Kertosono-Mojokerto, Tol Mojokerto-Surabaya, Tol Gempol-Pandaan, Tol Pandaan-Malang, Tol Gempol-Pasuruan, Tol Pasuruan-Probolinggo, Tol Probolinggo-Banyuwangi, Tol Gresik-Tuban, Tol KrianLegundi-Bunder-Manyar, Tol Tuban-Demak, Tol Surabaya-Suramadu-Tanjung Bulupandan, Tol Waru (Aloha)-Wonokromo-Tanjung Perak, dan Tol Bandara Juanda-Tanjung Perak.

Adapun secara garis besar menurut telaah studi literartur dan indepth interview, progress diketahui bahwa pencapaian pembangunan 14 ruas jalan tol tersebut belum mencapai $100 \%$. Lebih jelasnya mengenai progres pembangunan jalan tol di Provinsi Jawa Timur dapat dilihat pada Tabel 1 berikut:

Tabel 1. Progres Pembangunan Jalan Tol di Provinsi Jawa Timur

\begin{tabular}{|c|c|c|c|c|c|}
\hline \multirow{2}{*}{ No } & \multirow{2}{*}{ Nama Ruas } & \multirow{2}{*}{ BUJT } & \multirow{2}{*}{$\begin{array}{c}\text { Panjang } \\
(\mathbf{k m})\end{array}$} & \multicolumn{2}{|c|}{ Progres } \\
\hline & & & & Tanah & Konstruksi \\
\hline 1 & Mantingan-Ngawi & PT. $\quad$ Solo Ngawi & 122,55 & $97,90 \%$ & $57,23 \%$ \\
\hline 2 & Ngawi-Kertosono & $\begin{array}{ll}\text { Jaway, PT. } & \text { Nawi } \\
\text { Kertosono } & \text { Jaya, }\end{array}$ & & & \\
\hline 3 & Kertosono-Mojokerto & $\begin{array}{l}\text { Pemerintah-China } \\
\text { PT. Marga Harjaya } \\
\text { Infrastruktur }\end{array}$ & 40,50 & $99,89 \%$ & $\begin{array}{r}95,32 \% \\
\text { (target selesai } \\
2018)\end{array}$ \\
\hline 4 & Mojokerto-Surabaya & $\begin{array}{l}\text { PT. Jasa Marga } \\
\text { Surabaya Mojokerto }\end{array}$ & 36,27 & $100 \%$ & $\begin{array}{r}92,55 \% \\
\text { (target selesai } \\
2018)\end{array}$ \\
\hline 5 & Gempol-Pandaan & $\begin{array}{l}\text { PT. Jasa } \\
\text { Pandaan tol }\end{array}$ & 13,61 & $100 \%$ & $99,81 \%$ \\
\hline 6 & Pandaan-Malang & $\begin{array}{l}\text { PT. Jasa Marga } \\
\text { Pandaan-Malang }\end{array}$ & 38,68 & $68,39 \%$ & $\begin{array}{r}12,72 \% \\
\text { (target selesai } \\
2018)\end{array}$ \\
\hline 7 & Gempol-Pasuruan & $\begin{array}{l}\text { PT. Trans Marga } \\
\text { jatim Pasuruan }\end{array}$ & 34,15 & $76,47 \%$ & $\begin{array}{r}48,17 \% \\
\text { (target selesai } \\
2018)\end{array}$ \\
\hline
\end{tabular}




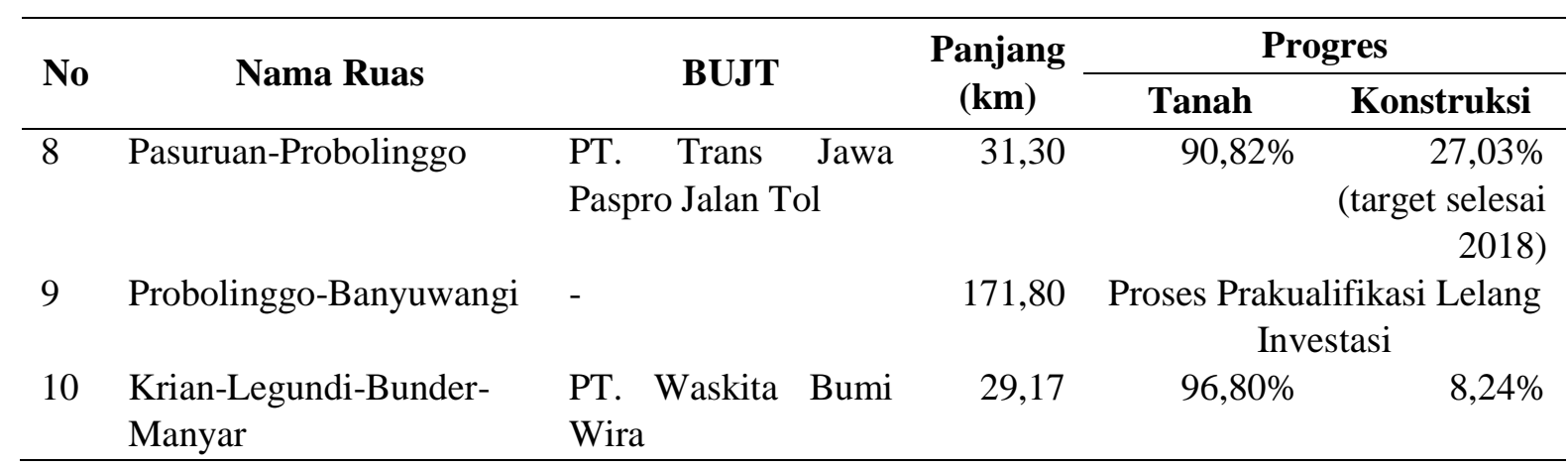

Sumber: Buku Progres Jalan Tol di Provinsi Jawa Timur per Status 21 Agustus 2017, Dinas Pekerjaan Umum Bina Marga Provinsi Jawa Timur, 2017

Berdasarkan pengumpulan data sekunder dari Dinas Pekerjaan Umum Bina Marga Provinsi Jawa Timur dalam buku Progres Jalan Tol di Provinsi Jawa Timur per Status 21 Agustus 2017 diatas dan hasil indepth interview yang telah dilakukan, dapat disimpulkan progres percepatan penyelesaian pengembangan jalan tol di Provinsi Jawa Timur dibagi dalam 3 (tiga) kelompok besar yaitu telah dilaksanakan, sedang dilaksanakan, dan belum dilaksanakan dengan penjabaran sebagai berikut:

\section{- Kategori Telah Dilaksanakan}

Yang termasuk dalam kategori telah terlaksana adalah jika pelaksanaan pembebasan lahan telah lebih dari $60 \%$. Adapun pengembangan jalan tol yang masuk dalam kategori telah terlaksana meliputi:

- Ruas Gempol-Pandaan sepanjang 13,61 km dengan progres pembebasan tanah sebesar $100 \%$ dan progres konstruksi sebesar 99,1\%. Seperti yang diketahui, Jalan Tol Gempol-Pandaan saat ini telah beroperasi dengan baik.

- Ruas Mantingan-Ngawi dan Ruas Ngawi-Kertosono sepanjang 122 km dengan progres pembebasan tanah sebesar 97,90\% dan progres konstruksi sebesar 57,23\%.

- Ruas Kertosono-Mojokerto sepanjang 40,50 km dengan progres pembebasan tanah sebesar 99,89\% dan progres konstruksi sebesar 95,32\%.

- Ruas Surabaya-Mojokerto sepanjang 36,27 km dengan progres pembebasan tanah sebesar 100\% dan progres konstruksi sebesar 92,55\%.

- Ruas Pandaan-Malang sepanjang 36,68 km dengan progres pembebasan tanah sebesar 68,39\% dan progres konstruksi sebesar 12,72\%. Pembangunan Tol Pandaan-Malang sendiri ditargetkan selesai pada Tahun 2018.

- Ruas Gempol-Pasuruan sepanjang 34,15 km dengan progres pembebasan tanah sebesar 76,47\% dan progres konstruksi sebesar 48,17\%. Pembangunan Tol Gempol-Pasuruan sendiri ditargetkan selesai pada Tahun 2018.

- Ruas Pasuruan-Probolinggo sepanjang 31,30 km dengan progres pembebasan tanah sebesar 90,82\% dan progres konstruksi sebesar 27,03\%. Pembangunan Tol Pasuruan-Probolinggo sendiri ditargetkan selesai pada Tahun 2018.

- Ruas Krian-Legundi-Bunder-Manyar sepanjang 29,17 km dengan progres pembebasan tanah sebesar 96,80\% dan progres konstruksi sebesar 8,24\%.

\section{- Sedang Dilaksanakan}

Yang termasuk dalam kategori sedang dilaksanakan adalah apabila penyusunan dokumen perencanaan detail masih dalam proses lelang maupun pelaksanaan pembebasan telah dilakukan namun masih kurang dari $60 \%$. Ruas tol yang masuk dalam kategori ini adalah:

- Ruas Probolinggo-Banyuwangi yang saat ini masih dalam proses prakualifikasi lelang investasi. 


\section{- Belum Dilaksanakan}

Yang termasuk dalam kategori belum terlaksana adalah jika belum terdapat dokumen perencanaan detail jalan tol dan terjadi perubahan dinamika pembangunan. Adapun pengembangan jalan tol yang masuk dalam kategori belum terlaksana meliputi:

- Ruas Bandara Juanda-Tanjung Perak yang saat ini belum ada dokumen perencanaan detail

- Ruas Surabaya-Suramadu-Tanjung Bulupandan yang saat ini belum ada dokumen perencanaan detail

- Ruas Gresik-Tuban yang saat ini belum ada dokumen perencanaan detail

- Ruas Tuban-Demak yang saat ini belum ada dokumen perencanaan detail

- Ruas Waru-Wonokromo-Tanjung Perak yang mana saat ini terjadi perubahan Rencana Tata Ruang Wilayah (RTRW) Kota Surabaya yang tidak mencantumkan trase jalan tol ini

Secara garis besar, ketercapaian program pembangunan jalan tol tersebut dapat dilihat pada Gambar 1 berikut ini:

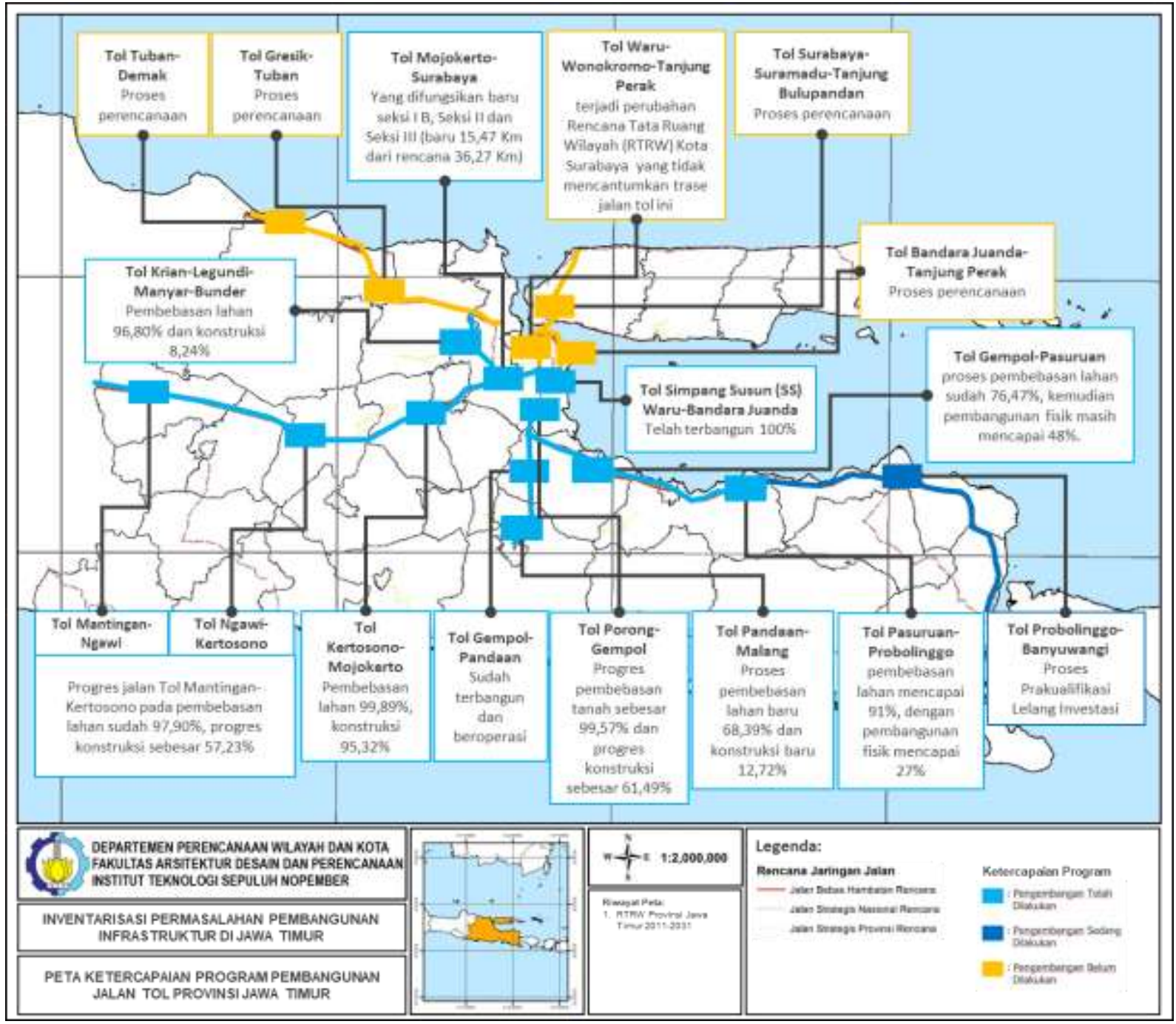

Gambar 1. Ketercapaian dan Simpangan Program Pembangunan Jalan Tol Provinsi Jawa Timur 
Setelah diketahui ketercapaian dan simpangan masing-masing program diatas, maka selanjutnya dirumuskan list penyebab permasalahan dalam pembangunan jalan tol di Provinsi Jawa Timur. Kendala-kendala tersebut dijabarkan sebagai berikut:

- Ruas Probolinggo-Banyuwangi diketahui bahwa hingga saat ini masih dalam proses prakualifikasi lelang investasi.

- Ruas Bandara Juanda-Tanjung Perak yang saat ini belum ada dokumen perencanaan detail, hal tersebut dikarenakan program pengembangan jalan tol pada ruas ini bukan menjadi prioritas pengembangan, serta karena terdapat perbedaan tahun perencanaan antara dokumen sektoral dan RTRW.

- Ruas Surabaya-Suramadu-Tanjung Bulupandan yang saat ini belum ada dokumen perencanaan detail, hal tersebut dikarenakan program pengembangan jalan tol pada ruas ini bukan menjadi prioritas pengembangan, serta karena terdapat perbedaan tahun perencanaan antara dokumen sektoral dan RTRW.

- Ruas Gresik-Tuban yang saat ini belum ada dokumen perencanaan detail. Pada Kabupaten Lamongan, trase tol ini belum tercantum dalam RTRW, sedangkan trase tol ini sudah tercantum dalam RTRW Kabupaten Tuban. Namun hingga saat ini belum ada pembahasan di daerah mengenai perencanaan detail trase tol ini.

- Ruas Tuban-Demak yang saat ini belum ada dokumen perencanaan detail, hal tersebut dikarenakan program pengembangan jalan tol pada ruas ini bukan menjadi prioritas pengembangan, serta karena terdapat perbedaan tahun perencanaan antara dokumen sektoral dan RTRW.

- Ruas Waru-Wonokromo-Tanjung Perak. Pemasalahan utama dalam pengembangan ruas ini adalah terjadi perubahan muatan dalam RTRW Kota Surabaya yang tidak mencantumkan trase jalan tol tersebut. Hingga saat ini belum didapatkan titik terang terhadap penyelesaian permasalahan pada trase jalan tol ini.

- Ruas Pandaan-Malang. Berdasarkan indepth interview diketahui bahwa kendala utama pada pengembangan ruas Tol Pandaan-Malang ini adalah pada pengadaan lahan. Diketahui terdapat 59 (lima puluh sembilan) bidang tanah di Kabupaten Pasuruan, 14 (empat belas) bidang tanah di Kabupaten Malang, dan 7 (tujuh) bidang tanah di Kota Malang yang perlu dikonsinyasikan, dan dalam hal ini akan dikoordinasikan oleh PPK dengan penyampaian surat permohonan konsinyasi ke Pengadilan Negeri. Selain itu di Kabupaten Malang terkendala banyaknya tanah kas desa (TKD) yang sulit untuk dibebaskan

- Ruas Gempol-Pasuruan dimana proses pembebasan lahan sudah 76,47\%, kemudian pembangunan fisik masih mencapai $48 \%$. Kendala utama pada pengembangan Tol Gempol-Pasuruan adalah pada pengadaan tanah. Permasalahan pembebasan tanah tersebut akan dijelaskan per masing-masing seksi:

- Pada Seksi I, terdapat 2 (dua) bidang yang belum dapat dikonstruksi karena menunggu amaning PN Bangil.

- Pada Seksi II, jumlah bidang yang dikonsinyasi ada 28 (dua puluh delapan) bidang dan sedang dilakukan proses penggantian tanah pengganti milik Pemda (KTD) dan sedang mengajukan permohonan penggantian Nadzir (Wakaf).

- Pada Seksi III, diketahui bahwa 1 bidang sertifikat hilang, 12 (dua belas) bidang menunggu persetujuan tanah sisa, dan 11 (sebelas) bidang persiapan validasi. Selain itu pada Kabupaten Pasuruan sedang dilakukan proses penggantian tanah milik pengganti milik Pemda (TKD).

- Ruas Pasuruan-Probolinggo dengan kendala utama adalah pengadaan tanah. Untuk tanah wakaf, proses penggantiannya sudah disampaikan ke Departemen Agama Kabupaten untuk diteruskan kepada Menteri Agama di Jakarta. Untuk tanah kas desa (TKD) sedang dalam proses penyampaian ke Bupati untuk rekomendasi dan diteruskan 
kepada Gubernur untuk pelepasannya. Sementara itu terdapat sisa bidang warga yang belum terbayar dikarenakan adanya administrasi waris yang belum diselesaikan.

- Ruas Krian-Legundi-Bunder-Manyar sepanjang 29,17 km dengan progres pembebasan tanah sebesar $96,80 \%$ dan progres konstruksi sebesar 8,24\%. Kendala utama yang dihadapi adalah pengadaan tanah dimana terdapat aset desa seluas $116 \mathrm{~m} 2$ yang masih belum ada tanah pengganti, pihak Desa masih mencari tanah pengganti, selain itu terdapat tanah warga yang belum jelas kepemilikannya (tanpa nama), dan perlu dikonsinyasi.

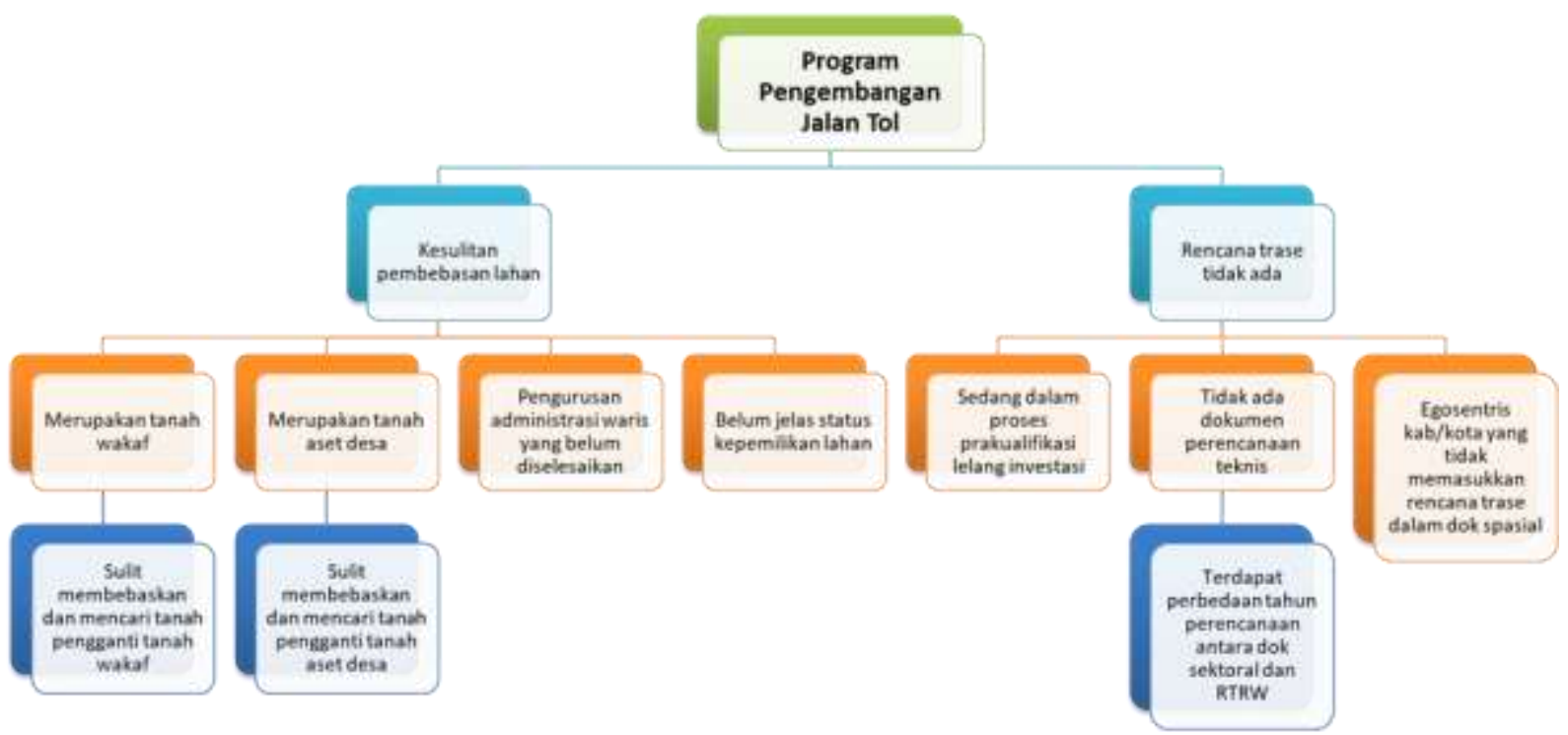

Gambar 2. Analisa Pohon Masalah dalam Pengembangan Jalan Tol di Provinsi Jawa Timur

Secara garis besar berdasarkan penjabaran dan gambar diatas, dapat disimpulkan bahwa terdapat 3 (tiga) faktor utama dalam pembangunan jalan tol di Provinsi Jawa Timur yaitu:

1) Kendala teknis yang meliputi permasalahan pembebasan tanah wakaf, permasalahan pembebasan tanah aset desa, permasalahan pengurusan administrasi waris, dan permasalahan kejelasan status kepemilikan lahan.

2) Kendala perencanaan yang meliputi permasalahan proses lelang dan permasalahan belum adanya dokumen perencanaan teknis; dan

3) Kendala kelembagaan yang meliputi pPermasalahan egosentris kabupaten/kota.

Tahap selanjutnya adalah merumuskan rekomendasi penyelesaian permasalahan dari program pengembangan jalan tol di Provinsi Jawa Timur sebagaimana penjabaran berikut:

1. Rekomendasi penyelesaian permasalahan pembebasan tanah wakaf

Pada dasarnya, harta benda wakaf dilarang untuk dijadikan jaminan, dijual, ditukar, atau dialihkan dalam bentuk pengalihan hak lainnya kecuali apabila harta benda wakaf yang telah diwakafkan digunakan untuk kepentingan umum sesuai dengan rencana umum tata ruang (RUTR) berdasarkan ketentuan peraturan perundang-undangan yang berlaku dan tidak bertentangan dengan syariah (Sumber: Undang-Undang Nomor 41 Tahun 2004 tentang Wakaf).

Solusi yang dapat ditawarkan adalah pihak pemerintah dapat mengganti tanah wakaf dengan harta benda penukar yang memiliki Nilai Jual Objek Pajak (NJOP) sekurangkurangnya sama dengan NJOP harta benda wakaf, atau dapat dengan menukar harta wakaf dengan harta benda penukar yang berada di wilayah strategis dan mudah untuk dikembangkan, hal ini sesuai dengan Pasal 50 Peraturan Pemerintah Republik Indonesia 
Nomor 42 Tahun 2006 tentang Pelaksanaan Undang-Undang Nomor 41 Tahun 2004 tentang Wakaf.

2. Rekomendasi penyelesaian permasalahan pembebasan tanah aset desa

Pemerintah dapat mengganti rugi tanah aset desa sesuai harga yang menguntungkan desa dengan mempertimbangkan harga pasar dan Nilai Jual Objek Pajak (NJOP) dan uang tersebut harus digunakan untuk membeli tanah lain yang lebih baik dan berlokasi di desa setempat, hal ini sesuai dengan Pasal 15 Permendagri Nomor 4 Tahun 2007 tentang Pedoman Pengelolaan Kekayaan Desa.

Selain itu aset desa berupa tanah dapat dimanfaatkan dengan skema sewa, kerjasama pemanfaatan, dan bangun serah guna (Pasal 11 Permendagri Nomor 1 Tahun 2016 tentang Pengelolaan Aset Desa). Penjelasan masing-masing skema pemanfaatan aset desa tersebut adalah:

- Pemanfaatan aset desa berupa sewa : tidak merubah status kepemilikan aset desa dengan jangka waktu sewa paling lama 3 (tiga) tahun dan dapat diperpanjang.

- Pemanfaatan aset desa berupa kerjasama pemanfaatan : dilaksanakan guna mengoptimalkan daya guna dan hasil guna aset desa dengan pihak lain paling lama 15 (lima belas) tahun sejak perjanjian dan dapat diperpanjang.

- Pemanfaatan aset desa berupa bangun serah guna dilaksanakan apabila Pemerintah Desa memerlukan bangunan dan fasilitas bagi penyelenggaraan pemerintahan desa dengan jangka waktu paling lama 20 (dua puluh) tahun dan dapat diperpanjang.

3. Rekomendasi penyelesaian permasalahan pengurusan administrasi waris yang belum diselesaikan

Pemilik lahan (ahli waris) dapat mengajukan pengurusan Fatwa Waris ke Pengadilan Agama setempat dengan menyelesaikan persyaratan-persyaratan yang dibutuhkan, Fatwa Waris tersebut merupakan bukti kelengkapan untuk proses pengurusan baik itu jual beli atau peralihan hak atas tanah warisan. Adapun jangka waktu penyelesaian surat Fatwa Waris tersebut harus sudah diputus atau diselesaikan dalam jangka waktu 6 (enam) bulan (sesuai dengan Surat Edaran Mahkamah Agung Nomor 3 Tahun 1998 tentang Penyelesaian Perkara).

4. Rekomendasi penyelesaian permasalahan kejelasan status kepemilikan lahan

Pengurusan masalah ganti rugi tanah dengan status kepemilikan lahan yang belum jelas dapat dititipkan di pengadilan (sistem konsinyasi), hal ini sesuai dengan Peraturan Presiden Nomor 71 Tahun 2012 tentang Penyelenggaraan Pengadaan Tanah Bagi Pembangunan untuk Kepentingan Umum.

5. Rekomendasi penyelesaian permasalahan proses lelang

Seperti yang diketahui, proses lelang pembangunan ruas-ruas jalan tol dilakukan oleh Pemerintah melalui Kementrian Pekerjaan Umum dan Perumahan Rakyat (PUPERA) c.q. Badan Pengatur Jalan Tol (BPJT). Proses lelang ruas-ruas jalan tol dilakukan dengan mengundang investor-investor yang tertarik untuk berinvestasi di sektor jalan tol. Investor-investor ini adalah BUJT yang bisa merupakan Badan Usaha Milik Negara (BUMN), Badan Usaha Milik Daerah (BUMD), swasta murni atau BUJT yang kepemilikan sahamnya gabungan dari ketiganya. Pada kasus proyek Tol ProbolinggoBanyuwangi, Pemerintah telah membuka lelang proyek tersebut sejak akhir April 2017 dengan harapan proses lelang tersebut akan selesai dalam waktu lima bulan (September 2017). Proses yang terjadi sekarang adalah proses lelang tersebut masih dalam tahap prakualifikasi lelang investasi. Rekomendasi penyelesaian masalah ini adalah dengan bekerjasama antar Pemerintah dan pihak terkait lainnya dalam percepatan proses lelang.

6. Rekomendasi penyelesaian permasalahan perbedaan tahun perencanaan antara dokumen sektoral dan RTRW 
Seperti yang diketahui, pada ruas Tol Gresik-Tuban, rencana trase jalan tol ini belum tertuang dalam RTRW Kabupaten Lamongan (namun telah tertuang dalam RTRW Kabupaten Tuban dan RTRW Kabupaten Gresik), rekomendasi penyelesaian untuk masalah ini adalah dengan koordinasi kelembagaan antar Pemerintah Pusat, Pemerintah Provinsi, dan Pemerintah Kabupaten (Gresik, Lamongan, Tuban) dalam perwujudan trase tol ini. Pada trase tol lainnya, diperlukan suatu pendekatan kelembagaan antar sektor dalam penyusunan program RTRW agar terjadi kesinkronan antara dokumen sektoral level provinsi dan RTRW provinsi itu sendiri.

7. Rekomendasi penyelesaian permasalahan egosentris kabupaten/kota

Permasalahan ini terjadi pada ruas Tol Waru-Wonokromo-Tanjung Perak Surabaya dimana terjadi perubahan RTRW Kota Surabaya yang tidak mencantumkan trase jalan tol ini. Pihak Pemerintah dan Pemerintah Kota Surabaya akan berkoordinasi dalam penyelesaian permasalahan ini. Rekomendasi dari Kementerian Pekerjaan Umum adalah dengan mengajukan opsi trase jalur tol melewati pinggiran Kota Surabaya (rencana terakhir akan melintasi dari Aloha Waru, menuju Jalan Ahmad Yani hingga Wonokromo kemudian belok kanan lewat Jagir Wonokromo hingga MERR lalu tembus ke arah Suramadu dan berakhir di Tanjung Perak) atau dengan menerapkan sistem jaringan radian jalan tol daripada sistem tol dalam kota.

\section{KESIMPULAN}

Hasil akhir yang didapatkan dalam penelitian ini adalah diketahui bahwa sampai saat ini pembangunan jalan tol di Provinsi Jawa Timur belum terlaksana hingga 100\%. Hal ini terjadi akibat adanya perbedaan tahun perencanaan program antara dokumen sektor level Nasional dengan dokumen perencanaan berupa RTRW Provinsi Jawa Timur 2011-2031, selain itu pada beberapa ruas pembangunan jalan tol masih ditemui kendala terkait pembebasan lahan. Kendala terkait pembebasan lahan diantaranya yaitu sulitnya mencari tanah pengganti untuk tanah wakaf dan tanah asset desa, pengurusan administrasi tanah waris, dan belum jelasnya status kepemilikan lahan. Adapun jika dilihat secara persentase, maka diketahui bahwa permasalahan pembangunan ruas jalan tol akibat adanya kendala teknis adalah sebesar $50 \%$, kendala perencanaan sebesar $40 \%$, dan kendala kelembagaan sebesar $10 \%$.

\section{DAFTAR PUSTAKA}

Basuki, S. (2006). Metode Penelitian. Wedatama Widya Sastra. Jakarta.

Kodoatie, R.J. (2005). Pengantar Manajemen Infrastruktur. Pustaka Pelajar. Yogyakarta.

Scavarda, A. J., Bouzdin-Chameeva, T., Goldstein, S., Hays, J., \& Hill, A. (2004). A review of the causal mapping practice and research literature. In Second World Conference on POM and 15th Annual POM Conference.

Suprayitno, H. \& Soemitro, H. (2018). "Preliminary Reflexion on Basic Principle of Infrastructure Asset Management". Jurnal Manajemen Aset Infrastruktur \& Fasilitas, Vol. 2, No. 1, Maret 2018, Hal. : 1-9.

Suryabrata, S. (1983). Metode Penelitian. CV Rajawali. Jakarta. 
(e)ISSN 2615-1847 (p)ISSN 2615-1839

Jurnal Manajemen Aset Infrastruktur \& Fasilitas - Vol. 2, Sup. 2, Desember 2018 